\title{
THE EFFECT OF MICROELEMENTS SUPPLEMENTATION ON $\beta$-OXIDATION ACTIVITY IN HEALTHY AND TYPE 1 DIABETIC RATS
}

\author{
Tomasz Kuryl' ${ }^{1}$, Bogdan Debski ${ }^{1}$, Karel Martinik ${ }^{2}$ \\ ${ }^{1}$ Department of Physiological Sciences, Faculty of Veterinary Medicine, Warsaw University of Life Sciences, Poland \\ ${ }^{2}$ Pedagogical Faculty, Hradec Králové University, Hradec Králové, Czech Republic
}

\begin{abstract}
SUMMARY
Diabetes mellitus type 1 disease changes the activity of fatty acid degradation as compared to healthy animals. Supplementation in vitro with microelements chromium $\mathrm{Cr}^{3+}$ and selenium $\mathrm{Se}^{4+}$ and $\mathrm{Se}^{2-}$ in non-toxic ( $[96.15 \mu \mathrm{mol}(5 \mathrm{ppm})$ for chromium and $6.33 \mu \mathrm{mol}(0.5 \mathrm{ppm})$ for selenium] concentrations strongly stimulates the activity of this process in diabetic rats. In healthy animals only chromium $\mathrm{Cr}^{3+}$ in concentration of $96.15 \mu \mathrm{mol}(5 \mathrm{ppm})$ stimulated $\beta$-oxidation activity in lymphocytes. It may indicate the beneficial effect of supplementation of the diet with microelements, chromium $\mathrm{Cr}^{3+}$ and selenium $\mathrm{Se}^{4+}$ or $\mathrm{Se}^{2-}$ at concentrations as low as $100 \mu \mathrm{mol}$ for chromium and $6 \mu \mathrm{mol}$ for selenium, respectively.
\end{abstract}

Key words: microelements, type 1 diabetes mellitus, rats, $\beta$-oxidation

Address for correspondence: T. Kuryl, Department of Physiological Sciences, Faculty of Veterinary Medicine, Warsaw University of Life Sciences - SGGW, Nowoursynowska 159, 02-776 Warsaw, Poland. E-mail:Tomasz_Kuryl@SGGW.pl

\section{INTRODUCTION}

Diabetes mellitus is one of the most important metabolic diseases in humans and animals. There are recognized two distinct form of this disease: type 1 (insulin dependent) and type 2 (insulin independent) form. Type 1 diabetes mellitus is the effect of insulin deficiency as the result of destruction of pancreatic B cells. Insulin injections restore the sugars utilization to the level comparable to those in healthy organisms. In type 2 diabetes mellitus insulin therapy is ineffective because of receptors abnormality, signaling defects. However, in some patient's identification of such changes is not possible. Insulin is responsible for entry of glucose into cells of muscle, adipose and other tissues, stimulation of storage of glucose in the form of glycogen in the liver and decreasing the glucose concentration in the blood. Insulin promotes the synthesis of fatty acids in the liver, which are used for synthesis of triacylglycerols, and has fat-sparing effect by preferential oxidation of sugars instead of fatty acids for energy production. In diabetic organisms metabolism of sugars is very limited. This energy source must be substituted by other group of compounds. In diabetes when insulin level is very low, lipolytic processes are not suppressed by this hormone, triacylglycerols from fat tissue are decomposed to glycerol and free fatty acids, which are metabolized to acetyl-CoA, the substrate for Krebs' cycle, and ketone bodies, acetoacetate and $\beta$-hydroxyl-butyrate. These compounds in diabetic organisms are partially metabolized to acetone.

Chromium ions (III) are recognized as a factor increasing glucose uptake in cells $(1,2)$. Important is the form of chromium compound. Hinigner et al. (3) reported, that chromium (III) had no toxic effect on DNA of human keratinocytes at concentrations of $250 \mu \mathrm{mol}$ for $\mathrm{CrCl}$ and Cr-histidinate, as well as $120 \mu \mathrm{mol}$ for chromium picolinate (saturating concentration). Chromium picolinate supplementation (80 $\mu \mathrm{g}$ per kilogram BW) resulted in diabetic rats in lowering of glucose level by $63 \%(\mathrm{p}<0.001)$, total cholesterol by $9.7 \%(\mathrm{p}<0.001)$ and triacylglycerols by $6.6 \%$ $(p<0.001)$ (4). Jain et al. (5) showed, that chromium picolinate, as well as chromium niacinate (400 $\mu$ g per kilogram BW) lowered not only triacylglycerols and cholesterol levels $(\mathrm{p}=0.04)$ but also TNF- $\alpha(p=0.04)$, IL-6 ( $p=0.02)$, C-reactive peptide $(p=0.02)$ and lipids peroxidation ( $\mathrm{p}=0.01$ ), which are increased in streptozotocin-induced diabetic rats. Chromium (VI) is recognized to be toxic for cells during reduction from $\mathrm{Cr}^{6+}$ to $\mathrm{Cr}^{3+}$ forming free reactive oxygen species (ROS) as intermediates $(6,7)$.

Selenium deficiency in humans manifests as Keshan disease, Kashin-Back disease and several kind of myopathies (8), what may suggest the potential participation of this ion in regulation of energy production processes. The reason of these pathologies is very low selenium level in the soil resulting in very low content of this essential trace element in food. The biologically active forms of selenium in organisms are glutathione peroxidase, 5'iodotyrosine deiodase, thioredoxine reductase and seleno-protein $P(9)$. Results of animal studies suggest that dietary selenium from inorganic or organic sources was toxic at concentrations exceeding $5 \mathrm{ppm}(63.3 \mu \mathrm{mol})$. Increasing degree of toxicity of this essential element was estimated as follows: seleniferous grains $>$ selenates $>$ selenites $>$ selenides and elemental selenium. Selenium intake recommendations are well known but the form of this supplementation is not taken into account. However, metabolic effects of various selenium oxidation state and compounds are often quite different. In plant fertilization inorganic forms are used - sodium selenite and/or sodium selenate mainly as additives of microelement fertilizers applied on leaves or directly to the soil (10). In organisms selenium is mostly present in the organic form of seleno-methionine and/or seleno-cysteine. 
We reported the action of chromium $\mathrm{Cr}^{3+}$, selenium $\mathrm{Se}^{4+}$ and $\mathrm{Se}^{2-}$ ions on glucose uptake and fatty acids degradation in healthy rats (11). The aim of presented studies was to study the effect of these ions, as well as L-carnitine supplementation on $\beta$-oxidation of fatty acids in healthy rats and rats with experimental diabetes mellitus type 1 .

\section{MATERIALS AND METHODS}

Animals: 14 male adult Wistar rats weighing 130-150 g were randomly divided into 2 groups of 7 rats each. Experimental animals were injected intraperitoneally with streptozotocin (50 $\mathrm{mg} / \mathrm{kg}$ body weight). All animals (healthy and diabetic) received a standard diet (AIN-93) having free access to food and drinking water. At the end of the experimental period, the animals were anesthetized by intraperitioneal injection of thiopental and blood was collected by heart puncture into the plastic tubes containing EDTA as an anticoagulant.

Methods: ß-oxidation activity of fatty acids was estimated according to Manning et al (12) in isolated lymphocytes in own modification (13). Lymphocytes were isolated by centrifugation on HISTOPAQUE-1077 (Sigma), resuspended in phosphate buffered saline (PBS) (calcium and magnesium free) up to a final concentration of approximately $1 \mathrm{mg} / \mathrm{ml}$ of protein. Lymphocytes (25-50 $\mu \mathrm{g}$ of protein) were incubated in a final volume of $200 \mu \mathrm{l}$ in triplicates for 60 minutes at $37^{\circ} \mathrm{C}$ in the presence of $50 \mu \mathrm{mol}$ palmitic acid in Hank's balanced salt solution (HBSS) supplemented with $1 \mathrm{mg} \cdot \mathrm{ml}^{-1}$ of fatty acids free bovine serum albumin (BSA) and $0.1 \mu \mathrm{Ci} / \mathrm{ml}$ of $[9,10]-{ }^{3} \mathrm{H}$-palmitic acid (Amersham). The reaction was terminated by the addition of $200 \mu \mathrm{l}$ of $10 \%$ trichloroacetic acid (TCA) and $100 \mu \mathrm{l}$ of HBSS. Precipitated fatty acid and protein were separated by centrifugation for $10 \mathrm{~min}$ at 3,000 rpm and supernatant was collected and alkalized with $100 \mu \mathrm{l}$ of $2 \mathrm{~mol} \mathrm{NaOH}$. The amount of liberated tritiated water, separated from remaining radioactive substrate on anion exchange column (0,5 × $2 \mathrm{~cm})$ (Bio-Rad AG 1X-8), depended on the activity of palmitic acid degradation, which was expressed as pmols of decomposed palmitic acid per $1 \mathrm{~min} \cdot 1 \mathrm{mg}^{-1}$ of lymphocytes protein.

Incubation media were supplemented with chromium ions $\left(\mathrm{Cr}^{3+}\right)$ in the form of chromium acetate, selenium ions $\left(\mathrm{Se}^{4+}\right)$ in the form of sodium selenite and selenium ions $\left(\mathrm{Se}^{2-}\right)$ in the form of seleno-L-methionine. Concentrations used were $96.15 \mu \mathrm{mol}$ (5 ppm) for chromium and $6.33 \mu \mathrm{mol}(0.5 \mathrm{ppm})$ for selenium ions. These concentrations are commonly recognized as nontoxic for animals.

Statistical analysis: The data are presented as the mean \pm SD of 7 experiments. Statistical differences between samples were calculated by Duncan test and t-test.

\section{RESULTS AND DISCUSSION}

The effect of microelements on fatty acids degradation was examined in healthy animals and in animals one week after injection with streptozotocin.

The effects on diabetes type 1 in rats injected with streptozotocin are shown in Table 1.
Table 1. The effect of streptozotocin injection on body weight gain and biochemical parameters of blood $(n=7$; Mean \pm S.D.)

\begin{tabular}{|l|l|c|c|}
\hline \multicolumn{2}{|c|}{ Parameter } & Healthy & Diabetic \\
\hline $\begin{array}{l}\text { Streptozotocin } \\
\text { treated }\end{array}$ & $\mathrm{mg} \cdot \mathrm{kg}^{-1}$ b.w. & 0 & $51.70 \pm 1.67$ \\
\hline Body weight gain & $\mathrm{g} \mathrm{per} \mathrm{week}$ & $55.00 \pm 3.21$ & $35.50 \pm 4,66^{\star}$ \\
\hline Insulin conc. & $\mathrm{pmol} \cdot \mathrm{dm}^{-3}$ & $552.10 \pm 174.70$ & $46.37 \pm 17.67^{\star}$ \\
\hline Glucose conc. & $\mathrm{mmol} \cdot \mathrm{dm}^{-3}$ & $5.34 \pm 0.54$ & $28.74 \pm 4.05^{\star}$ \\
\hline
\end{tabular}

* Differences in are statistically significant at $p=0.001$.

The used dose of streptozotocin caused drop of insulin from $552.10 \pm 174.70$ to $46.37 \pm 17.67 \mathrm{pmols} \cdot \mathrm{dm}^{-3}$ and increase of glucose level from $5.34 \pm 0.54$ to $28.74 \pm 4.05 \mathrm{mmol} \cdot \mathrm{dm}^{-3}$ in the blood of healthy and diabetic animals, respectively. The body weight gain after 7 days was $55.0 \pm 3.21 \mathrm{~g}$ for healthy Wistar rats as compared to $33.5 \pm 4.66 \mathrm{~g}$ for diabetic ones. Such animals were used for studies of the activity of $\beta$-oxidation of fatty acids.

The results of degradation of fatty acids by lymphocytes from healthy and diabetic rats after supplementation with ions of trace elements are presented in Table 2.

Table 2. The effect of chromium $\mathrm{Cr}^{3+}$ ions (96.15 mmol), selenium $\mathrm{Se}^{4+}$ and selenium $\mathrm{Se}^{2-}$ ions (6.33 $\mathrm{mmol}$ ) on fatty acids degradation in lymphocytes isolated from healthy and type 1 diabetic Wistar rats $(n=7)$.

\begin{tabular}{|l|c|c|c|}
\hline \multicolumn{1}{|c|}{$\begin{array}{c}\text { Media } \\
\text { enrichment }\end{array}$} & \multicolumn{3}{|c|}{$\begin{array}{c}\text { B-oxidation activity } \\
\text { pmol/min./mg of protein (mean } \pm \text { S.D.) }\end{array}$} \\
\hline & Healthy & Diabetic & Statistical Sig. P \\
\hline Control & $27.46 \pm 0.68^{\mathrm{d}}$ & $24.80 \pm 2.02^{\mathrm{a}}$ & 0.004 \\
\hline$+\mathrm{Cr}^{3+}$ & $45.02 \pm 1.10^{\mathrm{e}}$ & $54.43 \pm 3.93^{\mathrm{c}}$ & $<0.0001$ \\
\hline$+\mathrm{Se}^{4+}$ & $28.11 \pm 1.44^{\mathrm{d}}$ & $39.81 \pm 2.21^{\mathrm{b}}$ & $<0.0001$ \\
\hline$+\mathrm{Cr}^{r^{3+}},+\mathrm{Se}^{4+}$ & $22.84 \pm 0.64^{\mathrm{a}}$ & $33.41 \pm 2.07^{\mathrm{a}, \mathrm{b}}$ & $<0.0001$ \\
\hline$+\mathrm{Se}^{2-}$ & $26.51 \pm 0.75^{\mathrm{c}, \mathrm{d}}$ & $37.61 \pm 2.76^{\mathrm{a}, \mathrm{b}}$ & $<0.0001$ \\
\hline$+\mathrm{Cr}^{3+},+\mathrm{Se}^{2-}$ & $24.78 \pm 1.46^{\mathrm{b}}$ & $35.03 \pm 2.74^{\mathrm{b}}$ & $<0.0001$ \\
\hline
\end{tabular}

Means \pm S.D.

$(X)^{a \div e}-$ Means in column not sharing the same superscript letter are significantly different $(p<0.05)$

These data indicated, that in controls in diabetic rats the activity of fatty acid degradation was slightly lower as compared to the controls of healthy animals (24.80 \pm 0.72 and $27.46 \pm 0.20 \mathrm{pmol}$ $\cdot \mathrm{min}^{-1} \cdot \mathrm{mg}^{-1}$ of protein). This difference is statistically highly significant $(\mathrm{p}<0.001)$. Chromium $\mathrm{Cr}^{3+}$ ions are recognized as a very strong activators of glucose metabolism $(14,15)$ and $\beta$-oxidation process $(16,17)$ in healthy objects. Similar effect on the degradation of lipids may be observed when analyzing results of Brighenti et al. (18) and Letexier et al. (19) in volunteers fed with energy restricted diet. Increased activity of $\beta$-oxidation was also observed in healthy rats on the diet with non-digestible oliogofructans substituted for starch $(20,21)$. The effect of chromium ions was proportional to chromium and fibrous oligosugars concentration and was almost 2-times higher in experimental animals as compared to controls. The rate of activation of fatty acids decomposition is more effective in diabetic rats as compared to healthy ones (54.43 \pm 1.39 and $45.02 \pm 0.33$, respectively). Most probably it is 
caused by the loss of inhibitory effect of insulin, which is absent in diabetic objects (22). In healthy rats only the stimulatory effect of chromium $\mathrm{Cr}^{3+}$ was observed. One of the possible explanation of these observations might be the bioavailability of selenium ions, especially when in concentrations as low as $6.33 \mu \mathrm{mol}$ are accessible (23). All other combinations of ions were ineffective in modulation of the activity of fatty acids decomposition in healthy rats. On the other hand, in diabetic animals all variants of supplementation increased the activity of $\beta$-oxidation. However, the stimulatory effect was not as high as this observed for chromium alone. Additionally, fatty acids degradation was better stimulated by selenium $\mathrm{Se}^{4+}$ and $\mathrm{Se}^{2-}$ ions when used alone (39.81 \pm 2.21 and $37.61 \pm 2.76 \mathrm{pmol} \cdot \mathrm{min}^{-1} \cdot \mathrm{mg}^{-1}$ of protein, respectively) than in combination with chromium $\mathrm{Cr}^{3+}$. Combinations of chromium with selenium were not as effective as selenium $\mathrm{Se}^{4+}$ and $\mathrm{Se}^{2-}$ in stimulation of $\beta$-oxidation in lymphocytes isolated from the blood of diabetic rats $\left(33.41 \pm 2.07\right.$ and $35.03 \pm 2.74 \mathrm{pmol} \cdot \mathrm{min}^{-1} \cdot \mathrm{mg}^{-1}$ of protein, respectively).

The results of the activity of ß-oxidation presented as change in percent of control (Fig. 1) showed, that in healthy animals only chromium $\mathrm{Cr}^{3+}$ was effective as a stimulator of fatty acids degradation, however, in type 1 diabetic animals all ions of trace elements used separately were strong activators of this process. The most efficient was chromium (III) (120\% of stimulation as compared to control). Less effective were ions of selenium (IV) - $60 \%$ of stimulation and selenium (II) $-50 \%$ of stimulation. Simultaneous supplementation with chromium and selenium ions resulted in lower effectiveness as compared to variant contained individual ions.

In animal system selenium supplementation (selenium yeast) improve glucose levels (24) in diabetic hamster as well as the form of diphenyl diselenide exhibits benefitial effects against the development of diabetes in rats (25). Studies in humans are complicated because of commonly used supplementation with multivitamin and multimineral supplements $(26,27,28)$. In the case of chromium the effects of these trace elements are still discussed. Kleefstra et al. (29) reported that there is no evidence in improving glycemic control by chromium yeast, while Lai et al. (30) described beneficial action of this chromium prepara-

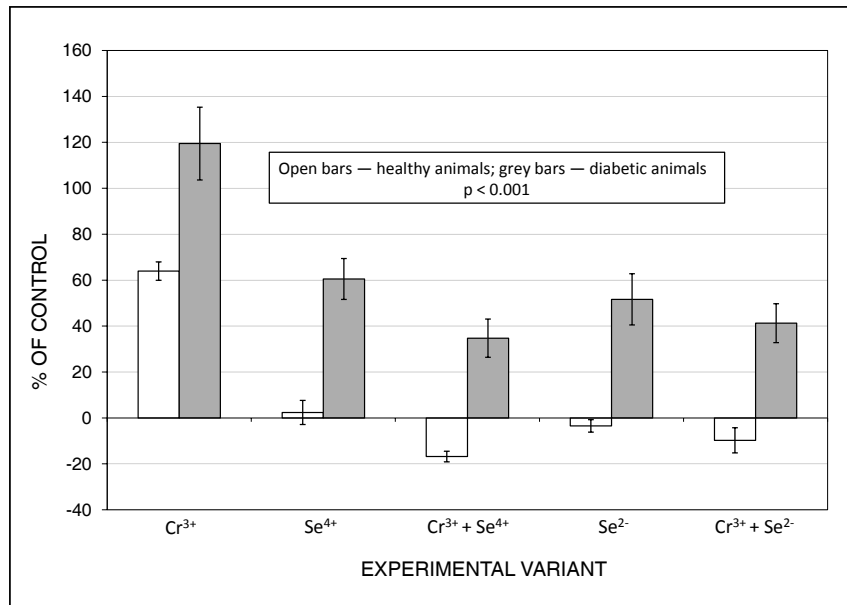

Fig. 1. Comparison of the efficiency of $\beta$-oxidation (expressed as change in percent of control) in lymphocytes from healthy and type 1 diabetic rats. Incubation mixtures were supplemented with $\mathrm{Cr}^{3+}$ ions (96.15 $\left.\mu \mathrm{mol}\right), \mathrm{Se}^{4+}$ and $\mathrm{Se}^{2-}$ ions $(6.33 \mu \mathrm{mol})($ mean \pm S.D.; $n=7)$. tion on carbohydrate and lipid metabolism. Differences between these studies were only in studied subjects - diabetic humans in Kleefstra's experiments and rats in Lai. The data presented by Kleefstra et al. (29) are questioned by a number of authors who found positive changes in carbohydrate and lipids metabolism after supplementation with other than chromium yeast supplements: chromium picolinate $(4,31)$, chromium niacinate $(5)$ or chromium-(D-phenylalanine) (32). Chromium ions improved lipids metabolism lowering LDL/HDL ratio and triacylglycerols concentration. These observations should be, in part, the effect of stimulation of fatty acids degradation as presented in this paper.

\section{CONCLUSIONS}

1. Chromium and selenium ions are very effective stimulators of fatty acids degradation.

2. Selenium ions $\left(\mathrm{Se}^{4+}\right.$ as well as $\left.\mathrm{Se}^{2-}\right)$ are less effective in stimulation of $\beta$-oxidation as compared to chromium $\mathrm{Cr}^{3+}$, especially in combination with chromium ions.

3. Combination of ions of microelements - chromium $\left(\mathrm{Cr}^{3+}\right)$ and selenium $\left(\mathrm{Se}^{4+}\right)$ and selenium $\left(\mathrm{Se}^{2-}\right)$ is beneficial for energy production in type-1 diabetic rats.

\section{Acknowledgement}

This work was supported by Warsaw University of Life Sciences as a grant No. 504-0231-0013.

\section{REFERENCES}

1. Lewicki S, Kuryl T, Debski B. The effect of boron and chromium (III) ions on energetical processes in bovine erythrocytes. Hradec Kralové: Faculty of Informatics and Management, University of Hradec Králové; 2005. (In Polish.)

2. Lipko M, Orzechowski A, Kuryl T, Debski B. Influence of chromium on glucose uptake in mouse myotubes. In: Anke M, Müller R, Schäfer U, Stoeppler M, editors. Mengen- und Spurenelemente. 21. Arbeitstagung Jena 2002. Leipzig: Schubert Verlag; 2002. p. 560-6.

3. Hininger I, Benaraba R, Osman M, Faure H, Roussel AM, Anderson RA. Safety of trivalent chromium complexes: no evidence for DNA damage in human HaCaT keratinocytes. Free Radic Biol Med. 2007 Jun 15;42(12):1759-65.

4. Sahin K, Onderci M, Tuzcu M, Ustundag B, Cikim G, Ozercan IH, et al. Effect of chromium on carbohydrate and lipid metabolism in a rat model of type 2 diabetes mellitus: the fat-fed, streptozotocin-treated rat. Metabolism. 2007 Sep;56(9):1233-40.

5. Jain SK, Rains JL, Croad JL. Effect of chromium niacinate and chromium picolinate supplementation on lipid peroxidation, TNF-alpha, IL-6, CRP, glycated hemoglobin, triglycerides, and cholesterol levels in blood of streptozotocintreated diabetic rats. Free Radic Biol Med. 2007 Oct 15;43(8):1124-31.

6. Matsumoto K, Takuwa A, Terashi A, Ui I, Okajo A, Endo K. Correlation between ketone body level in selenium-deficient rats and oxidative damages. Biol Pharm Bull. 2005 Jul;28(7):1142-7.

7. Arakawa H, Wu F, Costa M, Rom W, Tang MS. Sequence specificity of Cr(III)-DNA adduct formation in the p53 gene: NGG sequences are preferential adduct-forming sites. Carcinogenesis. 2006 Mar;27(3):639-45.

8. Ermakov VV. Urov Kashin-Beck disease: biogeochemical aspects. J Trace Elem Exp Med. 2004;17 Suppl 4:230.

9. Arnaud J, Akbaraly NT, Hininger I, Roussel AM, Berr C. Factors associated with longitudinal plasma selenium decline in the elderly: the EVA Study. J Nutr Biochem. 2007 Jul;18(7):482-7.

10. Debski B, Kuryl T, Gralak M. Foliar application of sodium selenite as a method of selenium enrichment of food. In: Circulation of the elements in environment: bioaccumulation, toxicity, protection. Warszaw: Institute of Environment Protection; 2001. p. 380-6. (In Polish.)

11. Kuryl T, Debski B, Bertrandt J, Klos A, Gralak M. The effect in vitro of chro- 
mium $\mathrm{Cr}+3$ and selenium Se +4 and selenium Se-2 on energetical processes in rats. Pol J Hum Nutr Metab. 2005;32 Suppl 1:301-6. (In Polish.)

12. Manning NJ, Olpin SE, Pollitt RJ, Webley J. A comparison of [9,10-3H] palmitic and $[9,10-3 \mathrm{H}]$ myristic acids for the detection of defects of fatty acid oxidation in intact cultured fibroblasts. J Inherit Metab Dis. 1990;13(1):58-68.

13. Kuryl T, Adamowicz M, Debski B, Bertrand J, Martynik K. Degradation of $[9,10-3 \mathrm{H}]$ - myristic acid by lymphocytes. Screening test of inherited disorders of activation, transport and mitochondrial oxidation of fatty acids. Aterosklerosa. 2001;23-6.

14. Davis CM, Sumrall KH, Vincent JB. A biologically active form of chromium may activate a membrane phosphotyrosine phosphatase (PTP). Biochemistry. 1996 Oct 1;35(39):12963-9.

15. Davis CM, Royer AC, Vincent JB. Synthetic multinuclear chromium assembly activates insulin receptor kinase activity: functional model for low-molecularweight chromium-binding substance. Inorg Chem. 1997;36:5316-20.

16. Kuryl T, Krejpcio Z, Wojciak R, Lipko M, Debski B. The in vitro effect of chromium $\mathrm{Cr}^{+3}$ and selenium $\left(\mathrm{Se}^{+4}\right.$ or $\left.\mathrm{Se}^{-2}\right)$ ions on carnitine uptake and fatty acids efficiency in rat's lymphocytes. In: Schubert R, Flachowsky G, Jahreis G, Bitsch R, editors. Vitamine und Zusatzstoffe in der Ernährung von Mensch und Tier. Jena: Friedrich Schiller University; 2005. p. 468-73.

17. Kuryl T, Lipko M, Debski B. Metabolism of fatty acids in broiler chicken is affected by chromium. In: Khassanova L, Collery P, Maymard I, Khassanova Z, Etienne JC, editors. Metal ions in biology and medicine. Paris: J. Libbey Eutotext; 2002. p. 454-9.

18. Brighenti F, Casiraghi MC, Canzi E, Ferrari A. Effect of consumption of a ready-to-eat breakfast cereal containing inulin on the intestinal milieu and blood lipids in healthy male volunteers. Eur J Clin Nutr. 1999 Sep;53(9):726-33.

19. Letexier D, Diraison F, Beylot M. Addition of inulin to a moderately highcarbohydrate diet reduces hepatic lipogenesis and plasma triacylglycerol concentrations in humans. Am J Clin Nutr. 2003 Mar;77(3):559-64.

20. Kuryl T, Krejpcio Z, Wojciak R, Lipko M, Debski B. The influence of chromium and fructan enriched diet on $\beta$ - oxidation activity of fatty acids in rat lymphocytes. In: Anke M, Flachowsky G, Kisters K, editors. Mengen- und Spurenelemente. 22. Arbeitstagung Jena 2004. Leipzig: Schubert Verlag; 2004. p. 401-5.

21. Kuryl T, Krejpcio Z, Wojciak R, Lipko M, Debski B. Fatty acids utilization in chromium (III) supplemented diabetic rats fed with mildenergy restricted diet. In: Schubert R, Flachowsky G, Jahreis G, Bitsch R, editors.
Vitamine und Zusatzstoffe in der Ernährung von Mensch und Tier. Jena: Friedrich Schiller University; 2005. p. 791-7.

22. Otto - Buczkowska E. Compendium on diabetes - pathology, diagnostic, and therapy. Bielsko-Biala: alpha-medica Press; 2003. (In Polish.)

23. Combs GF Jr. Considering chemical speciation in assessing trace element bioavailability: the case of selenium. J Trace Elem Exp Med. 2004;17 Suppl 4:254.

24. Agbor GA, Vinson JA, Patel S, Patel K, Scarpati J, Shiner D, et al. Effect of selenium- and glutathione-enriched yeast supplementation on a combined atherosclerosis and diabetes hamster model. J Agric Food Chem. 2007 Oct 17;55(21):8731-6.

25. Barbosa NB, Rocha JB, Soares JC, Wondracek DC, Gonçalves JF, Schetinger MR, et al. Dietary diphenyl diselenide reduces the STZ-induced toxicity. Food Chem Toxicol. 2008 Jan;46(1):186-94.

26. Bleys J, Navas-Acien A, Guallar E. Serum selenium and diabetes in U.S. adults. Diabetes Care. 2007Apr;30(4):829-34.

27. Bleys J, Navas-Acien A, Guallar E. Selenium and diabetes: more bad news for supplements. Ann Intern Med. 2007 Aug 21;147(4):271-2.

28. Al-Saleh E, Nandakumaran M, Al-Rashdan I, Al-Harmi J, Al-Shammari M. Maternal-foetal status of copper, iron, molybdenum, selenium and zinc in obese gestational diabetic pregnancies. Acta Diabetol. 2007 Sep;44(3):106-13.

29. Kleefstra N, Houweling ST, Bakker SJ, Verhoeven S, Gans RO, Meyboom-de Jong B, et al. Chromium treatment has no effect in patients with type 2 diabetes in a Western population: a randomized, double-blind, placebo-controlled trial. Diabetes Care. 2007 May;30(5):1092-6.

30. Lai MH, Chen YY, Cheng HH. Chromium yeast supplementation improves fasting plasma glucose and LDL-cholesterol in streptozotocininduced diabetic rats. Int J Vitam Nutr Res. 2006 Nov;76(6):391-7.

31. Mita Y, Ishihara K, Fukuchi Y, Fukuya Y, Yasumoto K. Supplementation with chromium picolinate recovers renal $\mathrm{Cr}$ concentration and improves carbohydrate metabolism and renal function in type 2 diabetic mice. Biol Trace Elem Res. 2005;105(1-3):229-48.

32. Yang X, Li SY, Dong F, Ren J, Sreejayan N. Insulin-sensitizing and cholesterol-lowering effects of chromium (D-Phenylalanine)3. J Inorg Biochem. 2006 Jul;100(7):1187-93.

Received November 26, 2007 Accepted in revised form January 28, 2008 